\title{
PENGARUH PEMBERIAN PUPUK ORGANONITROFOS PLUS,PUPUK ANORGANIK, DAN KOMBINASINYA TERHADAPBIOMASSA KARBON MIKROORGANISME (C-MIK) PADA TANAH ULTISOLS TAMAN BOGO YANG DITANAMI JAGUNG MANIS (Zea mays [L.] Saccharata Sturt)
}

\section{THE EFFECT OF ORGANONITROFOS PLUS FERTILIZER, ANORGANIC FERTILIZER, AND ITS COMBINATIONS ON MICROORGANISM CARBON BIOMASS (C-MIC) ON THE ULTISOLS LAND OF BOGO PARK PLANTED SWEET CORN (Zea mays [L.] Saccharata Sturt)}

\author{
Siti Bherliana Maharani Setiawati, Dermiyati, M.A. Syamsul Arif, Sri Yusnaini \\ Jurusan Agroteknologi, Fakultas Pertanian, Universitas Lampung \\ Jl Sumantri Brojonegoro 1, Bandar Lampung 35145, Indonesia \\ *Email: bherlianamaharai@gmail.com
}

\section{ABSTRACT}

This study aimed to find out the effect of giving organonitrofos plus fertilizers, inorganic fertilizers, and their combination on soil microorganism carbon biomass (C-mic) during the growth of sweet corn. The research was conducted at the Taman Bogo Research Institute, East Lampung from April to July 2016. The experimental design used was a randomized block design consisting of 11 combination treatments and 3 replications. The results showed that the $C$-mic of soil in all treatments combined with Organonitrofos plus and inorganic fertilizers was significantly higher by 25,45\% compared to the single treatment of Organonitrofos plus and single inorganic fertilizers at the 15 DAS (day after sowing) observation. Soil Cmic value in the single fertilizer treatment Organonitrofos plus, inorganic, and its combination was significantly higher 60,61\% compared to the treatment without fertilizer (control) at 30 DAS observations. The C-mic value of soil in the treatment of Organonitrofos plus $100 \%+100 \%$ inorganic fertilizer $\left(P_{0}\right)$ was significantly higher by 32,48\% compared to the treatment of various dosage combinations of Organonitrofos plus + inorganic fertilizers of $50 \%$ and $75 \%\left(P_{7}, P_{8}, P_{9}, P_{10}\right)$ at observation 30 DAS. The $C$-mic value of soil in the combination treatment of Organonitrofos plus 50\% $+50 \%$ inorganic $\left(P_{10}\right)$ fertilizers was significantly higher by 40,16\% compared to various combinations of doses of Organonitrofos plus $+75 \%$ inorganic fertilizers $\left(P_{7}, P_{8}, P_{9}\right)$ in 30 observations DAS.

Keywords: C-mic, inorganic fertilizers, organonitrofos plus fertilizers.

\begin{abstract}
ABSTRAK
Penelitian ini bertujuan untuk mengetahui pengaruh pemberian pupuk Organonitrofos plus, pupuk anorganik, dan kombinasinya terhadap biomassa karbon mikroorganisme (C-mik) tanah selama pertumbuhan jagung manis. Penelitian dilaksanakan di Balai Penelitian Taman Bogo, Lampung Timur pada bulan April sampai dengan Juli 2016. Rancangan percobaan yang digunakan adalah Rancangan Acak Kelompok yang terdiri dari 11 perlakuan kombinasi dan 3 ulangan. Hasil penelitian menunjukkan bahwa C-mik tanah pada semua perlakuan kombinasi pupuk Organonitrofos plus dan pupuk anorganik nyata lebih tinggi 25,45\% dibandingkan dengan perlakuan pupuk tunggal Organonitrofos plus maupun pupuk tunggal anorganik pada pengamatan 15 HST (hari setelah tanam). Nilai C-mik tanah pada perlakuan pupuk tunggal Organonitrofos plus, anorganik, maupun kombinasinya sangat nyata lebih tinggi 60,61\% dibandingkan dengan perlakuan tanpa pupuk (kontrol) pada pengamatan 30
\end{abstract}


HST. Nilai C-mik tanah pada perlakuan pupuk Organonitrofos plus 100\%+ anorganik 100\% ( $\left.\mathrm{P}_{6}\right)$ nyata lebih tinggi 32,48\% dibandingkan dengan perlakuan berbagai kombinasi dosis pupuk Organonitrofos plus + anorganik $50 \%$ dan 75\% $\left(\mathrm{P}_{7}, \mathrm{P}_{8}, \mathrm{P}_{9}, \mathrm{P}_{10}\right)$ pada pengamatan $30 \mathrm{HST}$. Nilai C-mik tanah pada perlakuan kombinasi pupuk Organonitrofos plus 50\% + anorganik 50\% $\left(\mathrm{P}_{10}\right)$ nyata lebih tinggi 40,16\% dibandingkan dengan.berbagai kombinasi dosis pupuk Organonitrofos plus + anorganik 75\% $\left(\mathrm{P}_{7}, \mathrm{P}_{8}, \mathrm{P}_{9}\right)$ pada pengamatan $30 \mathrm{HST}$.

Kata kunci: C-mik, pupuk anorganik, pupuk organonitrofos plus.

\section{PENDAHULUAN}

Produktivitas jagung manis di Indonesia, khususnya di Lampung saat ini masih belum optimal. Produksi jagung manis yang rendah selain disebabkan karena berkurangnya luas lahan panen, juga disebabkan oleh rendahnya kesuburan tanah.Sebagian besar lahan pertanian yang digunakan untuk budidaya jagung di Provinsi Lampung berjenis ultisols. Tanah ultisols umumnya memiliki kandungan hara yang rendah karena adanya pencucian basa yang berlangsung secara intensif dan miskin akan bahan organik. Tanah jenis ini mempunyai kadar Al yang tinggi sehingga dapat meracuni tanaman, kapasitas tukar kation rendah, serta peka terhadap erosi (Prasetyo dan Suriadikarta, 2006).Hasil penelitian Syafruddin dkk., (2014) menunjukkan bahwa jagung manis varietas Bonanza dapat lebih baik beradaptasi dengan lingkungan jika dibandingkan dengan varietas jago F1 dan Manise. Kemampuan dalam beradaptasi yang baik terhadap lingkungan akan berdampak pada produksi atau hasil tanaman itu sendiri.

Upaya untuk memperbaiki kesuburan tanah ultisol yaitu dengan teknologi pemupukan. Salah satu jenis pupuk organik yang dapat digunakan untuk memperbaiki kesuburan tanah ultisol adalah pupuk Organonitrofos yang merupakan hasil dari pengomposan kotoran sapi segar dan batuan fosfat alam yang diperkaya dengan mikroba penambat $\mathrm{N}$ dan pelarut P (Nugroho dkk., 2012). Namun, karena kualitas yang dihasilkan pupuk Organonitrofos masih rendah (kandungan C-organik, N, P dan K rendah) maka dikembangkan pupuk Organonitrofos plus yang menggunakan bahan baku kotoran sapi segar dengan berbagailimbah padat industri, mikroba penambat $\mathrm{N}$ dan pelarut P, serta Trichoderma spp(Dermiyati dkk., 2016).

Pemberian pupuk Organonitrofos plus dan kombinasinya dengan pupuk anorganikdiharapkan dapat memenuhi kebutuhan unsur hara di dalam tanah yang dapat meningkatkanbiomassa mikroorganisme tanah sehingga kesuburan tanah meningkat. Pengukuran C-mik tanah dapat dijadikan indikator dalam penentu kesuburan tanah. Hal ini karena C-mik tanah dapat mewakili sebagian kecil fraksi total karbon di dalam tanah. Penelitian Nugroho dkk. (2012) menunjukkan bahwa pemberian pupuk Organonitrofos dengan dosis $2.000 \mathrm{~kg} \mathrm{ha}^{-1}$ dan kombinasinya terhadap pupuk anorganik dengan dosis $100 \mathrm{~kg}$ urea ha-1, 50 kg TSP ha ${ }^{-1}, 100 \mathrm{~kg} \mathrm{KCl} \mathrm{ha-1} \mathrm{secara} \mathrm{sinergis} \mathrm{dapat}$ menghasilkan tinggi tanaman dan bobot brangkas lebih baik daripada taraf dosis kombinasi lainnya terhadap tanaman jagung. Selain itu, Airlangga (2015) menyatakan bahwa selama pertumbuhan tanaman jagung, pada kombinasi perlakuan $\mathrm{P}_{4}$ yaitu pupuk Organonitrofos 75\% (3.750 kg Organonitrofos ha-1) 
dan pupuk anorganik 25\% (150 kg Urea ha ${ }^{-1}, 62,5 \mathrm{~kg}$ SP-36 ha' ${ }^{-1}, 50 \mathrm{~kg} \mathrm{KCl} \mathrm{ha-1)} \mathrm{dan} \mathrm{P}_{5}$ yaitu pupuk Organonitrofos $100 \%\left(5.000 \mathrm{~kg} \mathrm{ha}^{-1}\right)$ menghasilkan nilai C-mik lebih tinggi dibandingkan perlakuan lainnya.

Penelitian ini dilakukan untuk mengetahui pengaruh pemberian pupuk Organonitrofos plus, pupuk anorganik, dan kombinasinya terhadap biomassa karbon mikroorganisme(C-mik) selama pertumbuhan tanaman jagung manis.

\section{BAHAN DAN METODE}

Penelitian dilaksanakan di Kebun Percobaan Balai Besar Penelitian dan Pengembangan Sumberdaya Lahan Pertanian (BBSDLP) Taman Bogo, Probolinggo, Lampung Timur pada bulan April sampai dengan Juli 2016. Analisis tanah dilakukan di Laboratorium Ilmu Tanah, Jurusan Agroteknologi, Fakultas Pertanian, Universitas Lampung dari bulan Agustus sampai dengan Oktober 2016.

Pupuk Organonitrofos plusdiaplikasikan bersamaan dengan dolomit dan biochar pada 1 minggu sebelum tanam. Selanjutnya, pengaplikasian pupuk urea dilakukan sebanyak dua kali. Aplikasi pupuk urea pertama sebanyak $1 / 2$ dosis diberikan secara bersamaan dengan pupuk $\mathrm{KCl}$ dan SP-36 yaitu pada 1 minggu setelah benih jagung ditanam(MST), dan aplikasi pupuk urea kedua sebanyak $1 / 2$ dosis dilakukan pada 6 MST.

Rancangan percobaan yang digunakan adalah Rancangan Acak Kelompok (RAK) yang terdiri dari 11 perlakuan dengan 3 ulangan. Perlakuan disajikan pada Tabel 1. Homogenitas data diuji dengan uji Bartlett dan aditivitas data diuji dengan uji Tukey. Data yang diperoleh diuji menggunakan analisis ragam dan perbedaan nilai tengah dengan uji Ortogonal Kontras.Selama pertumbuhan tanaman dilakukan pengamatan biomassa karbon mikroorganisme (C-mik) tanah pada 78 HST (panen). Variabel pendukung yang diamati berupa sifat fisik dan kimia tanah antara lain C-organik tanah, $\mathrm{pH}$ tanah, suhu tanah, kadar air tanah, dan N-total tanah pada saat 78 HST. Dilakukan korelasi antara sifat tanah pada saat panen dengan Cmik tanah.

Tabel 1. Perlakuan Aplikasi Pupuk Organonitrofos Plus dan Pupuk Anorganik

\begin{tabular}{|c|c|c|c|c|c|c|}
\hline \multirow{3}{*}{ Perlakuan } & \multicolumn{2}{|c|}{ Kombinasi Pupuk } & \multirow{2}{*}{\multicolumn{4}{|c|}{ Dosis Pupuk (kg per petakan) }} \\
\hline & $\mathrm{OP}$ & Anorg & & & & \\
\hline & \multicolumn{2}{|r|}{$(\%)$} & Urea & SP-36 & $\mathrm{KCl}$ & Organonitrofos \\
\hline $\mathrm{P}_{0}$ & 0 & 0 & - & - & - & - \\
\hline $\mathrm{P}_{1}$ & 0 & 100 & 1,35 & 0,68 & 0,34 & - \\
\hline $\mathrm{P}_{2}$ & 100 & 0 & - & - & - & 22,50 \\
\hline $\mathrm{P}_{3}$ & 100 & 25 & 0,34 & 0,17 & 0,08 & 22,50 \\
\hline $\mathrm{P}_{4}$ & 100 & 50 & 0,68 & 0,34 & 0,17 & 22,50 \\
\hline $\mathrm{P}_{5}$ & 100 & 75 & 1,01 & 0,51 & 0,25 & 22,50 \\
\hline $\mathrm{P}_{6}$ & 100 & 100 & 1,35 & 0,68 & 0,34 & 22,50 \\
\hline $\mathrm{P}_{7}$ & 25 & 75 & 1,01 & 0,51 & 0,25 & 5,63 \\
\hline $\mathrm{P}_{8}$ & 50 & 75 & 1,01 & 0,51 & 0,25 & 11,25 \\
\hline $\mathrm{P}_{9}$ & 75 & 75 & 1,01 & 0,51 & 0,25 & 16,88 \\
\hline $\mathrm{P}_{10}$ & 50 & 50 & 0,68 & 0,34 & 0,17 & 11,25 \\
\hline
\end{tabular}

Keterangan : Pupuk Organonitrofos plus $100 \%$ dosis (10.000 kg ha-1), pupuk anorganik 100\% dosis (600 kg urea ha- $1,300 \mathrm{~kg}$ SP-36 ha-1, dan $150 \mathrm{~kg} \mathrm{KCl}$ ha-1) ); (-) = tidak diberikan pupuk. 


\section{HASIL DAN PEMBAHASAN}

Pengaruh Pemberian Pupuk Organonitrofos Plus,

Pupuk Anorganik, dan Kombinasinya terhadap

Biomassa Karbon Mikroorganisme (C-mik) Tanah

Hasil pengamatan (Tabel 2) menunjukkan bahwa perlakuan kombinasi pupuk Organonitrofos plus dan pupuk anorganik berpengaruh nyata terhadap Cmik tanah pada 15 dan 30 HST. Hal ini diduga karena adanya akumulasi bahan organik yang berasal dari tanaman sebelumnya dan pupuk Organonitrofos plus yang diaplikasikan. Akumulasi bahan organik seperti seresah tanaman dapat menjadi sumber bahan organik, sehingga dapat meningkatkan nilai $\mathrm{C}$-mik di dalam tanah. Selain itu, adanya peningkatan $\mathrm{CO}_{2}$ yang berasal dari lingkungan rhizosfer juga dapat menyebabkan mikroorganisme di dalam tanah ikut meningkat. Menurut Rodrigues-Lionaz dkk. (2008), organisme tanah mempengaruhi pertumbuhan tanaman dan organisme lain yang hidup di dalam tanah dan sebaliknya. Tanaman dapat mempengaruhi keberadaan dan komposisi mikroorganisme rhizosfer.

Nilai C-mik tanah pada perlakuan kombinasi pupuk Organonitrofos plus dan pupuk anorganik $\left(\mathrm{P}_{3}\right.$ sampai dengan $\left.\mathrm{P}_{10}\right)$ nyata lebih tinggi $25,45 \%$ dibandingkan dengan perlakuan pupuk tunggal anorganik $\left(\mathrm{P}_{1}\right)$ dan pupuk tunggal Organonitrofos plus $\left(\mathrm{P}_{2}\right)$ pada 15 HST (Tabel2).Penggunaan pupuk organik saja diduga dapat meningkatkan unsur hara di dalam tanah, tetapi dengan tingkat hasil yang rendah.Oleh karena itu, pemberian kombinasi pupuk Organonitrofos plus dan pupuk anorganik baik dilakukan guna meningkatkan produktivitas tanah dan tanaman secara berkelanjutan dan ramah lingkungan.

Selanjutnya, C-mik tanah pada perlakuan pupuk tunggal Organonitrofos plus, anorganik, maupun kombinasinya $\left(\mathrm{P}_{1}\right.$ sampai dengan $\left.\mathrm{P}_{10}\right)$ sangat nyata lebih

Tabel 2. Pengaruh Pemberian Pupuk Organonitrofos Plus, Pupuk Anorganik, dan Kombinasinya terhadap C-mik Tanah pada Tanah yang Ditanami Jagung Manis (Zea mays [L.] Saccharata Sturt).

\begin{tabular}{|c|c|c|c|c|c|}
\hline \multirow{2}{*}{ Perbandingan } & \multicolumn{5}{|c|}{ \% Selisih dan Signifikansi } \\
\hline & $15 \mathrm{HST}$ & $30 \mathrm{HST}$ & $45 \mathrm{HST}$ & $60 \mathrm{HST}$ & 78 HST \\
\hline $\mathrm{P}_{0}$ vs sisa & $5,70^{\text {tn }}$ & $60,61^{* *}$ & $10,23^{\text {tn }}$ & $-4,47^{\text {tn }}$ & $16,51^{\text {tn }}$ \\
\hline $\mathrm{P}_{1}$ vs $\mathrm{P}_{2}$ & $-10,93^{\text {tn }}$ & $-20,52^{\text {tn }}$ & $15,10^{\text {tn }}$ & $6,13^{\mathrm{tn}}$ & $-16,31^{\text {tn }}$ \\
\hline $\mathrm{P}_{1}, \mathrm{P}_{2}$ vs sisa & $25,45 *$ & $-5,71^{\mathrm{tn}}$ & $2,51^{\text {tn }}$ & $10,12^{\mathrm{tn}}$ & $33,57^{\text {tn }}$ \\
\hline $\mathrm{P}_{3}, \mathrm{P}_{4}, \mathrm{P}_{5}$ vs $\mathrm{P}_{6}$ & $-5,18^{\mathrm{tn}}$ & $23,31^{\text {tn }}$ & $8,80^{\text {tn }}$ & $1,58^{\mathrm{tn}}$ & $-4,59^{\mathrm{tn}}$ \\
\hline $\mathrm{P}_{4}, \mathrm{P}_{5}$ vs $\mathrm{P}_{3}$ & $-6,39^{\mathrm{tn}}$ & $-23,65^{\text {tn }}$ & $-1,13^{\text {tn }}$ & $-11,83^{\mathrm{tn}}$ & $-22,08^{\text {tn }}$ \\
\hline $\mathrm{P}_{4}$ vs $\mathrm{P}_{5}$ & $-3,37^{\text {tn }}$ & $21,16^{\text {tn }}$ & $-5,99^{\text {tn }}$ & $-8,42^{\text {tn }}$ & $1,07^{\mathrm{tn}}$ \\
\hline $\mathrm{P}_{7}, \mathrm{P}_{8}, \mathrm{P}_{9}, \mathrm{P}_{10}$ vs $\mathrm{P}_{6}$ & $-12,98^{\mathrm{tn}}$ & $32,48 *$ & $16,03^{\text {tn }}$ & $24,76^{\mathrm{tn}}$ & $16,54^{\text {tn }}$ \\
\hline $\mathrm{P}_{7}, \mathrm{P}_{8}, \mathrm{P}_{9} \mathrm{vs}_{10}$ & $29,95^{\text {tn }}$ & $40,16 *$ & $10,79^{\text {tn }}$ & $-24,71^{\mathrm{tn}}$ & $-10,14^{\text {tn }}$ \\
\hline $\mathrm{P}_{8}, \mathrm{P}_{9}$ vs $\mathrm{P}_{7}$ & $12,83^{\text {tn }}$ & $-28,74^{\mathrm{tn}}$ & $7,14^{\text {tn }}$ & $3,55^{\mathrm{tn}}$ & $16,27^{\text {tn }}$ \\
\hline $\mathrm{P}_{8}$ vs $_{9}$ & $0,79^{\text {tn }}$ & $-14,88^{\text {tn }}$ & $11,06^{\text {tn }}$ & $-13,27^{\mathrm{tn}}$ & $10,01^{\text {tn }}$ \\
\hline
\end{tabular}

Keterangan : HST $=$ hari setelah tanam, tn $=$ tidak berbeda nyata pada taraf $5 \%, *=$ berbeda nyata pada taraf $5 \%, * *=$ berbeda nyata pada taraf $1 \%$. $\mathrm{P}_{0}$ (kontrol), $\mathrm{P}_{1}$ (anorganik 100\%), $\mathrm{P}_{2}$ (Organonitrofos plus $\left.100 \%\right), \mathrm{P}_{3}$ (Organonitrofos plus $100 \%+$ anorganik 25\%), $\mathrm{P}_{4}$ (Organonitrofos plus 100\% + anorganik 50\%), $\mathrm{P}_{5}($ Organonitrofos plus 100\% + anorganik 75\%), $\mathrm{P}_{6}\left(\right.$ Organonitrofos plus 100\% + anorganik 100\%), $\mathrm{P}_{7}($ Organonitrofos plus $25 \%+$ anorganik $75 \%), \mathrm{P}_{8}($ Organonitrofos plus 50\% + anorganik $75 \%), \mathrm{P}_{9}$ (Organonitrofos plus $75 \%+$ anorganik $\left.75 \%\right), \mathrm{P}_{10}$ (Organonitrofos plus 50\% + anorganik 50\%). 
tinggi 60,61\% dibandingkan dengan perlakuan tanpa pupuk/kontrol $\left(\mathrm{P}_{0}\right)$ pada $30 \mathrm{HST}$ (Tabel 2). Nilai Cmik tanah pada kontrol merupakan nilai terendah, karena lahan yang ada tidak diberikan perlakuan pupuk Organonitrofos plus maupun pupuk anorganik sehingga diduga tidak ada substrat yang dapat dimanfaatkan oleh mikroorganisme tanah. Penambahan pupuk Organonitrofos plus sebagai bahan organik baik dilakukan karena dapat menjadi sumber energi bagi mikroorganisme tanah sehingga akan meningkatkan nilai C-mik tanah. Semakin banyak bahan organik yang ditambahkan ke dalam tanah, maka akan meningkatkan populasi mikroorganisme tanah. Hal ituakan berdampak pada peningkatan jumlah mikroorganisme tanah yang menyebabkan biomassa karbon mikroorganisme (Cmik) di dalam tanah juga akan meningkat.

Berdasarkan hasil uji ortogonal kontras pada pengamatan $30 \mathrm{HST}$ ( Tabel 2), nilai C-mik tanah pada perlakuan 100\% kombinasi pupuk Organonitrofos plus dan $100 \%$ dosis pupuk anorganik $\left(\mathrm{P}_{6}\right)$ nyata lebih tinggi $32,48 \%$ dibandingkan dengan perlakuan $50 \%$ dan $75 \%$ dosis pupuk anorganik dengan berbagai kombinasi dosis pupuk Organonitrofos plus di bawah 100\% dosis $\left(\mathrm{P}_{7}, \mathrm{P}_{8}, \mathrm{P}_{9}, \mathrm{P}_{10}\right)$. Perlakuan $\mathrm{P}_{6}$ diduga dapat menunjang pertumbuhan jagung manis, sehingga dapat memberikan pengaruh yang nyata terhadap nilai C-mik tanah. Hal ini didukung oleh penelitian Putra (2017) yang menyatakan bahwa kombinasi 100\% pupuk Organonitrofos plus dan $100 \%$ pupuk NPK $\left(\mathrm{T}_{6}\right)$ memberikan pengaruh terbaik terhadap fase generatif yang ditunjukkan pada variabel tinggi tongkol utama, bobot basah tongkol, bobotkering tongkol, bobot tongkol dengan kelobot dan bobot tongkol tanpa kelobot.

Perlakuan 50\% dosis pupuk Organonitrofos plus dan 50\% dosis pupuk anorganik $\left(\mathrm{P}_{10}\right)$ pada 30 HST nyata lebih tinggi 40,16\% dibandingkan dengan perlakuan berbagai kombinasi dosis pupuk Organonitrofos plus dan 75\% dosis pupuk anorganik $\left(\mathrm{P}_{7}, \mathrm{P}_{8}, \mathrm{P}_{9}\right)($ Tabel 2). Pemberian kombinasi pupuk Organonitrofos plus dan pupuk anorganik yang tepat mampu meminimalisir hilangnya unsur hara di dalam tanah, sehingga dapat menunjang pertumbuhan tanaman dan meningkatkan nilai C-mik tanah. Hal tersebut didukung oleh penelitian Sari (2015) yang menyatakan

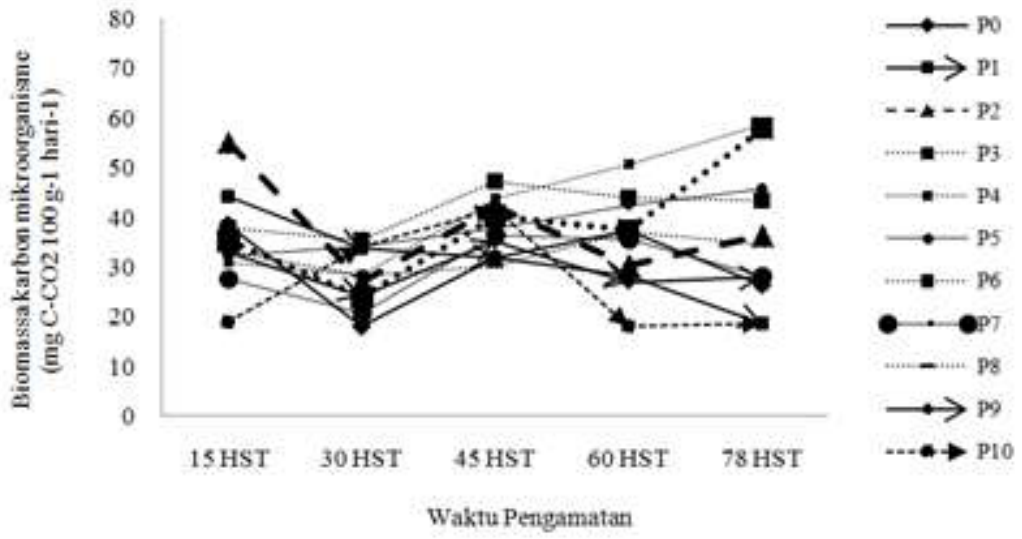

Gambar 1. Dinamika perkembangan C-mik tanah dengan perlakuan kombinasi pupuk Organonitrofos dan pupuk anorganik pada tanah ultisol yang ditanami jagung manis (Zea mays [L.] Saccharata Sturt). 
bahwa perlakuan dengan dosis urea $150 \mathrm{~kg} \mathrm{ha}^{-1}, \mathrm{SP}-$ $36100 \mathrm{~kg} \mathrm{ha}^{-1}, \mathrm{KCl} 50 \mathrm{~kg} \mathrm{ha}{ }^{-1}$, dan pupuk Organonitrofos $1.500 \mathrm{~kg} \mathrm{ha}^{-1}$ mampu meningkatkan serapan hara $\mathrm{N}, \mathrm{P}$, dan $\mathrm{K}$ total pada tanaman jagung manis. Hal ini diduga dapat membuktikan bahwa pemberian pupuk organik berupa pupuk Organonitrofos plus yang tepat mampu mengurangi penggunaan pupuk anorganik.

Nilai C-mik tanah pada seluruh perlakuan kombinasi pupuk Organonitrofos plus dan pupuk anorganik mengalami fluktuasi (Gambar 1). Secara umum C-mik tanah pada 15 HST meningkat kemudian pada 30 HST menurun, dan pada 45 HST sampai 78 HST meningkat kembali. Menurut Purwoko (2007), mikroorganisme akan mengalami beberapa fase setelah diaplikasikan bahan organik ke dalam tanah. Fase tersebut antara lain fase lambat (lag phase), fase naik (exponential phase), fase seimbang (stationary phase), dan fase mati (death phase).

\section{Sifat Tanah Taman BogoPada Saat Panen (78 HST)}

Berdasarkan hasil analisis sifat kimia tanah (Tabel 3), dapat dilihat bahwa terjadi peningkatan kesuburan tanah di lahan penelitian Taman Bogo setelah aplikasi pupuk. Kriteria $\mathrm{pH}$ tanah sebelum diberikan perlakuan pemupukan bersifat masam dengan $\mathrm{pH} 4,61$. Setelah diaplikasikan pupuk Organonitrofos dan anorganik, $\mathrm{pH}$ tanah mengalami peningkatan sebesar 5,11-5,63 dengan kriteria agak masam. Hal ini menunjukkan walaupun terjadi peningkatan $\mathrm{pH}$ tanah, kondisi tingkat kemasaman tanah di Taman Bogo masih tergolong masam hingga agak masam. Menurut Nugroho dkk. (2012), pH ideal untuk menunjang pertumbuhan jagung manis yaitu sebesar 5,5 hingga 7,5. Nilai $\mathrm{pH}$ tanah yang meningkat diduga karena adanya penambahan pupuk Organonitrofos yang menyebabkan asam-asam organik hasil dekomposisi akan mengikat $\mathrm{Al}$, sehingga Al-tidak terhidrolisis lagi.

\section{Uji Korelasi antara Beberapa Sifat Tanah dengan}

\section{C-mik Tanah}

NilaiC-organiktanah, $\mathrm{pH}$ tanah, suhu tanah, Ntotal dan kadar air tanah pada78 HST tidak berkorelasi nyata dengan $\mathrm{C}$-mik tanah (Tabel 4).Tidak terdapat korelasi antara $\mathrm{C}$-organik tanah dengan $\mathrm{C}$-mik tanah (Tabel 4). Rendahnya kandungan C-organik tanah diduga karena $\mathrm{C}$-organik yang ada di dalam tanah masih sedikit dan belum dapat memberikan pengaruh terhadap keberadaan mikroorganisme tanah. Selain itu, singkatnya waktu penelitian yang digunakan disebabkan oleh bahan organik yang belum terdekomposisi secara keseluruhan menjadi C-organik. Sibuea (2014) menyatakan bahwa waktu penelitian yang singkat merupakan penyebab C-organik tidak dapat memberikan pengaruh yang nyata. Untuk mendapatkan kadar C-organik yang tinggi memerlukan waktu yang lama.

Demikian pula tidak terdapat korelasi antara kadar air tanah dengan C-mik tanah (Tabel 4). Hal ini terjadi karena mikroorganisme dan tanaman membutuhkan kondisi yang optimum untuk pertumbuhan hidupnya. Kadar air pada lahan penelitian yaitu berkisar $30 \%$. Rendahnya kadar air tanah disebabkan karena penelitian dilakukan saat musim panas.Suhu udara dari bulan April hingga Juli tahun 2016 berkisar $26,6-27,6^{\circ} \mathrm{C}$ dengan curah hujan bulanan 
Tabel 3. Analisis Beberapa Sifat Tanah Ultisol Taman Bogo pada Saat Panen

\begin{tabular}{lccccc}
\hline \multicolumn{1}{c}{ Perlakuan } & $\begin{array}{c}\mathrm{pH} \\
\left(\mathrm{H}_{2} \mathrm{O}\right)\end{array}$ & $\begin{array}{c}\text { Suhu } \\
\left({ }^{\circ} \mathrm{C}\right)\end{array}$ & $\begin{array}{c}\text { C-organik } \\
(\%)\end{array}$ & \multicolumn{2}{c}{ Kadar air } \\
$(\%)$
\end{tabular}

Keterangan : Angka yang diikuti huruf menyatakan $\mathrm{SR}=$ sangat rendah, $\mathrm{R}=$ rendah, $\mathrm{AM}=$ agak masam, $\mathrm{M}=$ masam. Kriteria bersumber dari Balai Penelitian Tanah (2009).

Tabel 4. Ringkasan Uji Korelasi antara Sifat Tanah dengan C-mik Tanah Pada Pengamatan 78 HST (panen)

\begin{tabular}{llcc}
\hline \multicolumn{1}{c}{ Variabel } & Persamaan Korelasi & Koefisien Korelasi (r) & F hitung \\
\hline C-organik tanah dengan C-mik & $\mathrm{y}=0,5 \mathrm{x}+34,0$ & 0,55 & $2,28^{\mathrm{tn}}$ \\
pH tanah dengan C-mik & $\mathrm{y}=6,6 \mathrm{x}-71,6$ & 0,15 & $0,79^{\mathrm{tn}}$ \\
Suhu tanah dengan C-mik & $\mathrm{y}=0,7 \mathrm{x}+21,0$ & 0,06 & $0,00^{\mathrm{tn}}$ \\
Kadar air tanah dengan C-mik & $\mathrm{y}=0,8 \mathrm{x}-59,8$ & 0,12 & $0,50^{\mathrm{tn}}$ \\
N-total tanah dengan C-mik & $\mathrm{y}=4,3 \mathrm{x}-13,3$ & 0,28 & $2,65^{\mathrm{tn}}$ \\
\hline
\end{tabular}

Keterangan: $\mathrm{tn}=$ tidak berbeda nyata pada taraf $5 \%$

62-214 mm bulan ${ }^{-1}$. Menurut Syukur dan Rifianto (2013), umumnya jagung manis dapat tumbuh pada suhu $21-27^{\circ} \mathrm{C}$ dengan curah hujan 300-600 mm bulan-

1. Kondisi cuaca yang kurang mendukung pada penelitian ini menyebabkan produksi jagung manis yang dihasilkan tidak optimal. Dari hasil pengamatan, produksi bobot tongkol dengan kelobot jagung manis yang ada yaitu 4,47-17,64 ton $\mathrm{ha}^{-1}$.

Suhu tanah berkorelasi negatif terhadap C-mik tanah (Tabel 4). Jadi, semakin tinggi suhu tanah maka nilai C-mik akan menurun. Suhu yang optimum akan mendukung pertumbuhan mikroorganisme tanah. Sumarsih (2003) menyatakan bahwa mikroorganisme tanah dapat dibagi menjadi 3 kelompok berdasarkan kisaran suhu pertumbuhannya yaitu kelompok mikroorganisme psikrofil $\left(0^{\circ} \mathrm{C}-30^{\circ} \mathrm{C}\right)$, mesofil $\left(25^{\circ} \mathrm{C}-\right.$ $\left.37^{\circ} \mathrm{C}\right)$, dan termofil $\left(55^{\circ} \mathrm{C}-60^{\circ} \mathrm{C}\right)$. Kisaran suhu tanah pada penelitian ini adalah $22,67-23^{\circ} \mathrm{C}$. Oleh karena itu pada lahan penelitian ini diduga memiliki kelompok mikroorganisme mesofil sehingga menghendaki suhu yang sedang untuk pertumbuhannya.

Berdasarkan data hasil uji korelasi C-mik dengan N-total tanah (Tabel 4), nilai C-mik tanah tidak berkorelasi dengan N-total. Hal ini diduga karena nitrogen yang diberikan ke dalam tanah langsung dimanfaatkan oleh tanaman, sehingga tidak dapat 
dimanfaatkan oleh mikroorganisme tanah. Tanaman akan langsung menyerap $\mathrm{N}$ yang akan bermanfaat bagi pertumbuhannya.

\section{KESIMPULAN}

Berdasarkan hasil penelitian, dapat disimpulkan bahwa C-mik tanah pada semua perlakuan kombinasi pupuk Organonitrofos plus dan pupuk anorganik nyata lebih tinggi $25,45 \%$ dibandingkan dengan perlakuan pupuk tunggal Organonitrofos plus maupun pupuk tunggal anorganik pada pengamatan 15 HST.Pada pengamatan 30 HST, C-mik tanah perlakuan pupuk tunggal Organonitrofos plus, pupuk anorganik, maupun kombinasinya sangat nyata lebih tinggi $60,61 \%$ dibandingkan dengan perlakuan tanpa pupuk (kontrol) Nilai C-mik tanah pada perlakuan pupuk Organonitrofos plus 100\% dan pupuk anorganik 100\% $\left(\mathrm{P}_{6}\right)$ nyata lebih tinggi 32,48\% dibandingkan dengan perlakuan berbagai kombinasi dosis pupuk Organonitrofos plus dan pupuk anorganik ( $50 \%$ dan $75 \%)\left(\mathrm{P}_{7}, \mathrm{P}_{8}, \mathrm{P}_{9}, \mathrm{P}_{10}\right)$. Nilai C-mik tanah pada perlakuan kombinasi pupuk Organonitrofos plus 50\% dan pupuk anorganik 50\% $\left(\mathrm{P}_{10}\right)$ nyata lebih tinggi $40,16 \%$ dibandingkan dengan berbagai kombinasi dosis pupuk Organonitrofos plus dan pupuk anorganik $75 \%\left(\mathrm{P}_{7}, \mathrm{P}_{8}, \mathrm{P}_{9}\right)$.

\section{UCAPAN TERIMAKASIH}

Penulis mengucapkan terimakasih kepada Universitas Lampung yang telah memfasilitasi sarana dan prasarana untuk kegiatan penelitian ini. Terimakasih juga disampaikan kepada Kepala Kebun Percobaan
Balai Besar Penelitian dan Pengembangan Sumberdaya Lahan Pertanian (BBSDLP) Taman Bogo Lampung Timur yang telah memberikan izin untuk pengambilan sampel tanah.

\section{DAFTAR PUSTAKA}

Airlangga, T.A. 2015. Pengaruh Pemberian Kombinasi Pupuk Organonitrofos dan Kimia, dengan Penambahan Biochar terhadap Biomassa Karbon Mikroorganisme (C-mik) pada Tanah Ultisol yang ditanami Jagung (Zea Mays L.). Skripsi. Universitas Lampung. Bandar Lampung. $56 \mathrm{hlm}$.

Dermiyati, S. D. Utomo., K. F. Hidayat., J. Lumbanraja., S. Triyono., H. Ismono., N. E. Ratna., N. T. Putri, dan R. Taisa. 2016. Pengujian Pupuk Organonitrofos Plus pada Jagung Manis (Zea mays saccharata. L) dan Perubahan Sifat Kimia Tanah Ultisols. Journal Trop Soils 21 (1): 9 - 17. DOI :10.5400/ jts.2016.21.1.9

Nugroho, S.G., Dermiyati, J. Lumbanraja, S. Triyono, H. Ismono, Y.T. Sari, and E. Ayuandari. 2012. Optimum Ratio of Fresh Manure and Grain Size of Phospate Rock Mixture in a Formulated Compost for Organomineral NP Fertilizer. J. Trops. Soils 17(2): 121-128. DOI: $10.5400 /$ jts.2012.17.2.121

Prasetyo, B.H., dan D.A. Suriadikarta. 2006. Karakteristik, Potensi, dan Teknologi Pengelolaan Tanah Ultisol untuk Pengembangan Pertanian Lahan Kering di Indonesia. J. Litbang Pertanian 25(2) : 39-40.

Purwoko, T. 2007. Fisiologi Mikroba. PT. Bumi Aksara. Jakarta. 
Putra, I.P. 2017. Pengaruh Pupuk Organonitrofos dan Kombinasinya dengan Pupuk Anorganik terhadap Pertumbuhan dan Produksi Jagung Manis (Zea Mays Saccharata) pada Tanah Ultisol Taman Bogo Lampung Timur. Skripsi. Universitas Lampung. Bandar Lampung.

Rodriguez-Lionaz, G., M. Onaindia, I. Amezaga, I. Mijangos and C. Garbisu. 2008. Relationship between Vegetation Diversitu and Soil Functional Diversity in Native Mixed-oak Forests.Soil Biology and Biochemistry 40 : 49-60. DOI: 10.1016/j.soilbio.2007.04.015

Sari, E.P. 2015. Uji Efektivitas Pupuk Organonitrofos dan Kombinasinya dengan Pupuk Kimia Terhadap Pertumbuhan, Serapan Hara, dan Produksi Tanaman Jagung Manis (Zea mays saccharata) di Musim Tanam Ketiga pada Tanah Ultisol Gedung Meneng. J. Penelitian Pertanian Terapan 15(3) : 174-182.
Sibuea, A.M.P. 2014. Pengaruh Olah Tanah dan Aplikasi Mulsa Bagas terhadap Populasi dan Biomassa Cacing Tanah pada Pertanaman Tebu Ratoon ke-2. Skripsi. Universitas Lampung. Bandar Lampung. 50 hlm.

Sumarsih, S. 2003. Mikrobiologi Dasar. Universitas Pembangunan Nasional Veteran. Yogyakarta. $116 \mathrm{hlm}$.

Syafruddin, Nurhayatidan R. Wati. 2014. Pengaruh Jenis Pupuk terhadap Pertumbuhan dan Hasil Beberapa Varietas Jagung Manis. J. Floratek 7: 107-114.

Syukur, M. dan A. Rifianto. 2013. Jagung Manis. Penebar Swadaya. Jakarta. $124 \mathrm{hlm}$. 